\title{
PEMAKAIAN KATA PENGHUBUNG DAN KATA DEPAN YANG TIDAK TEPAT DALAM BAHASA INDONESIA DI SMA MUHAMMADIYAH PRINGSEWU
}

\author{
Umi Kholidah $^{1}$, Ainur Rosidah ${ }^{2}$, Abiyyu Yahya ${ }^{3}$ \\ ${ }^{1,2,3}$ FKIP, Universitas Muhammadiyah Pringsewu \\ Email: kholidah@umpri.ac.id ${ }^{1}$
}

\begin{abstract}
Abstrak: Kegiatan pengabdian masyarakat ini dilaksanakan di SMA Muhammadiyah Pringsewu, yang dihadiri 17 peserta didik kelas X. Kegiatan ini bertujuan untuk memberikan pengetahuan kepada peserta didik dalam penggunaan konjungsi dan kata depan untuk penulisan karangan maupun laporan akhir. Kegiatan ini melalui dua tahapan yakni tahap perencanaan dan tahap pelaksanaan. Pada tahap perencanaan dilakukan analisis situasi untuk mengetahui permasalahan yang dialami sekolah mitra dan merancang materi kegiatan pelatihan terkait pemakaian kata penghubung dan kata depan yang tidak tepat dalam bahasa Indonesia pada penulisan laporan akhir peserta didik. Tahap pelaksanaan terdiri dari kegiatan penyampaian materi tentang pemakaian kata penghubung dan kata depan yang tidak tepat dalam bahasa Indonesia yang digunakan pada penulisan laporan akhir peserta didik. Hasil dari kegiatan ini adalah peserta didik kelas XII di SMA Muhammadiyah Pringsewu mengetahui cara pemakaian kata penghubung dan kata depan yang tidak tepat dalam bahasa Indonesia yang digunakan dalam penulisan laporan akhir sekolah.
\end{abstract}

Kata Kunci: pelatihan, kata hubung, kata depan, bahasa Indonesia

\section{PENDAHULUAN}

Bahasa merupakan salah satu alat komunikasi yang terpenting. Manusia dapat berhubungan dengan manusia lainnya karena adanya bahasa dalam kehidupan seharihari, baik secara lisan maupun tulisan. Interaksi antar manusia akan menghasilkan maksud yang dicapai secara baik apabila keduanya sama-sama memahami bahasa yang digunakan dalam pembicaraan. Penggunaan bahasa yang baik dan benar, baik secara lisan maupun tulisan merupakan tuntutan dalam berbahasa. Kesalahan penggunaan kata hubung dan kata depan yang tidak tepat dapat menjadikan bahasa terkesan ambigu dan rancu. Kesalahan tersebut sering terjadi pada penulisan karangan atau laporan kegiatan peserta didik. Salah-satunya adalah pemakaian konjungsi dan kata depan.

Kesalahan tulisan dalam konjugsi dan kata depan sering kali digunakan dalam awal kalimat. Hal itu merupakan hal yang kurang tepat, karena konjungsi itu terdapat 
dalam pertengahan kalimat atau awal kalimat yang terdapat dalam dua kausa atau lebih. Konjungsi digunakan untuk menghubungkan kata dengan kata, frasa dengan frasa, kalusa dengan klausa, atau kalimat dengan kalimat. Konjungsi diperlukan agar kata, kalimat, maupun paragraf di dalam suatu karangan akan menjadi teratur. Keteraturan itu sangat penting untuk meperlihatkan adanya suatu kepaduan diantara kata, kalimat, maupun paragraf satu dengan yang lainnya. Untuk itu, akan dikaji lebih lanjut mengenai konjungsi.

Penggunaan konjungsi harus berdasar pada kaidah-kaidah tertentu. Makna dari satuan-satuan bahasa dalam suatu kalimat maupun paragraf akan lebih jelas jika menggunakan konjungsi. Konteks kata, frasa, kalusa, atau kalimat yang berbeda menggunakan kata penghubung yang berbeda pula. Oleh karena itu, kita perlu mengetahui penggunaan konjungsi secara benar. Pemakaian konjungsi di dalam kalimat bukan untuk dapat menerangkan kata. Namun, tidak lebih dari sekedar alat penghubung yang berfungsi untuk dapat mempertegas serta memperpadu makna.

Selain konjungsi, kesalahan penulisan kata juga banyak terdapat pada kata depan atau disebut preposisi. Preposisi merupakan kata depan suatu kategori yang terletak di depan kategori lain, terutama kata benda (nomina) sehingga membentuk frasa eksosentrik direktif (Kridalaksana, 1986:93). Preposisi dan konjungsi merupakan dua kategori yang berbeda secara sintaksis perbedaan antara preposisi dan konjungsi terletak pada penggunaannya dalam kalimat. Preposisi menandai hubungan makna antarkata, antarfrasa, dan antarklausa saja. Semantara itu, konjungsi menandai hubungan komponen-komponen dalam tataran yang sama, yaitu hubungan antarkata, antarfrasa, dan antarklausa, antarkalimat, antarparagraf, serta hubungan komponenkomponen dalam tataran yang berbeda. Perbedaan lain, yakni preposisi lebih banyak berfungsi sebagai penjelas atau keterangan, sedangkan konjungsi terdapat dalam semua fungsi (Chaer, 1990:56).

Berdasarkan penelitian yang dilakukan oleh Nugraha (2015), kesalahan konjungsi sering terjadi pada penggunaan "dan", "tetapi", dan "lalu", sedangkan yang digunakan sebagai preposisi ejaan yang salah adalah "yg" dan "/". Baiti (2020) dan 
Amalia (2018) menyatakan dalam penelitiannya bahwa konjungsi dikelompokkan memjadi dua yaitu konjungsi koordinatif dan konjunsi subordinatif. Selain itu, dalam penelitia Sari (2020) menyatakan bahwa terdapat konjugsi koordinatif, konjungsi subordinarif, dan konjungsi korelatif.

Dari uraian di atas, diperlukan suatu kegiatan yang dikemas dalam bentuk pengabdian kepada masyarakat, dan kepada siswa yang didampingi oleh guru bahasa Indonesia untuk memberikan tambahan wawasan, dan pengetahuan tentang bagaimana siswa dapat menggunakan pemakaian kata penghubung dan kata depan secara baik dan benar dalam bahasa Indonesia, sehingga mampu menghasilkan sebuah tulisan yang baik dan benar dalam karangan maupun laporan kegiatan, khususnya masalah penulisan konjungsi dan kata depan. Adapun manfaat dari kegiatan ini adalah peserta didik mahir dalam menggunakan ketepatan konjungsi dan kata depan dalam menuliskan karangan maupun laporan akhir.

\section{METODE PELAKSANAAN}

Metode pelaksanaan pengabdian kepada masyarakat ini dilaksanakan sebagai bentuk upaya dalam memberikan solusi permasalahan yang dirasakan oleh peserta didik SMA Muhammadiyah Pringsewu dalam penggunaan konjungsi dan kata depan pada karya tulis. Kegiatan pelatihan ini dilaksanakan bekerjasama dengan mahasiswa Pendidikan Bahasa dan Sastra Indonesia. Peserta dalam kegiatan pelatihan ini adalah siswa kelas X SMA Muhammadiyah Pringsewu sebanyak 17 orang. Kegiatan ini dilakukan dalam dua tahap yakni perencanaan dan pelaksanaan. Tahap perencanaan diawali dari mempelajari permasalahan yang dihadapi oleh peserta didik dalam pemakaian kata penghubung dan kata depan yang tidak tepat dalam bahasa Indonesia yang digunakan dalam penulisan karangan maupun laporan akhir sekolah. Selanjutnya menyiapkan materi untuk pelaksanaan kegiatan pelatihan. Tahap pelaksanaan berisikan kegiatan penyampaian materi dan sesi Tanya jawab antara pemateri dengan peserta, kemudian peserta melakukan praktik penggunaan kalimat dengan pemakaian kata penghubung dan kata depan yang tidak tepat dalam bahasa 
Indonesia di depan kelas. Selanjutnya, peserta didik praktik secara langsung penulisan laporan akhir yang didampingi oleh mahasiswa di tempat.

\section{HASIL DAN PEMBAHASAN}

Berdasarkan hasil observasi mahasiswa yang terlibat dalam kegiatan pengabdian kepada masyarakat ini diperoleh data bahwa peserta didik dalam penulisan karangan maupun laporan akhir masih terkendala dalam pemakaian kata penghubung dan kata depan yang tidak tepat dalam bahasa Indonesia. Kondisi ini menumbuhkan rasa peduli dosen Pendidikan Bahasa dan Sasra Indonesia untuk memberikan pelatihan tentang pemakaian kata penghubung dan kata depan yang tidak tepat dalam bahasa Indonesia.

Konjungsi atau kata hubung adalah kategori yang berfungsi untuk meluaskan satuan yang lain dalam konstruksi hipotaktis, dan selalu menghubungkan dua satuan lain atau lebih dalam konstruksi (Kridalaksana, 2005:102). Dalam bahasa Indonesia sering dijumpai pemakaian bentuk-bentuk di mana, dalam mana, di dalam mana, dari mana, dan yang mana sebagai penghubung. Dalam bahasa Indonesia memang terdapat bentuk di mana, dari mana, dan yang mana, tetapi tidak lazim digunakan sebagai penghubung. Bentuk-bentuk itu lazimnya dipakai untuk menandai kalimat tanya. Bentuk di mana dan dari mana dipakai untuk menyatakan 'tempat', yaitu 'tempat berada' dan 'tempat asal', sedangkan yang mana untuk menyatakan 'pilihan'.

Menurut Ramlan (1980:16) preposisi merupakan kata tugas yang bertugas sebagai unsure pembentuk frasa preposisi. Selain itu, Kridalaksana (2005:95) menyatakan bahwa kata depan adalah kata yang secara sintaksis terdapat di depan nomina, adjektiva, atau adverbia dan secara semantis menandai berbagai hubungan makna antara konstituen di depan dan di belakang preposisi tersebut. Dalam penggunaan bahasa, orang harus cermat dengan kata depan karena kata depan itu secara semantik menandai pertalian antara kata atau frasa yang mengikutinya, atau yang disebut aksis, dengan kata atau frasa lain dalam kalimat atau frasa yang lebih besar. Sebagai contoh adalah kata depan di-. Kata depan ini digunakan antara lain 
untuk menandai makna 'tempat berada', seperti di sekolah, di sana, di Yogyakarta, dsb.

Pelaksanaan kegiatan pelatian pemakaian kata penghubung dan kata depan yang tidak tepat dalam bahasa Indonesia di SMA Muhammadiyah Pringsewu dilaksanakan pada hari Selasa 7 Deswmber 2021. Pada sesi penyampaian materi, materi tentang pemakaian kata penghubung dan kata depan yang tidak tepat dalam bahasa Indonesia disampaikan oleh Umi Kholidah dkk. Adapun materi yang disampaikan meliputi kesalahan penggunaan kata hubung (pemakaian bentuk-bentuk di mana, didalam mana, dari mana, dan yang mana sebagai penhubung dan penghubung kalimat majemuk), dan penyebab pemakaian kata depan yang tidak tepat dalam penulisan karangan mapun laporan akhir sekolah.

Pada saat penyampaian materi pelatihan diselingi dengan sesi tanya jawab. Pada kegiatan ini tim pengabdian yang terdiri dari Umi Kholidah, Ainur Rosidah, dan Abiyyu Yahya bersama-sama dalam menjawab pertanyaan dari peserta pengabdian secara bergantian. Rasa ingin tahu dari peserta pengabdian kepada masyarakat terkait materi pelatihan tersebut sangatlah besar. Hal ini ditunjukkan dengan banyaknya pertanyaan yang dipaparkan oleh peserta didik pada sesi ini. Berikut gambar antusias peserta pelatihan dalam kegiatan penyampaian materi dan sesi tanya.
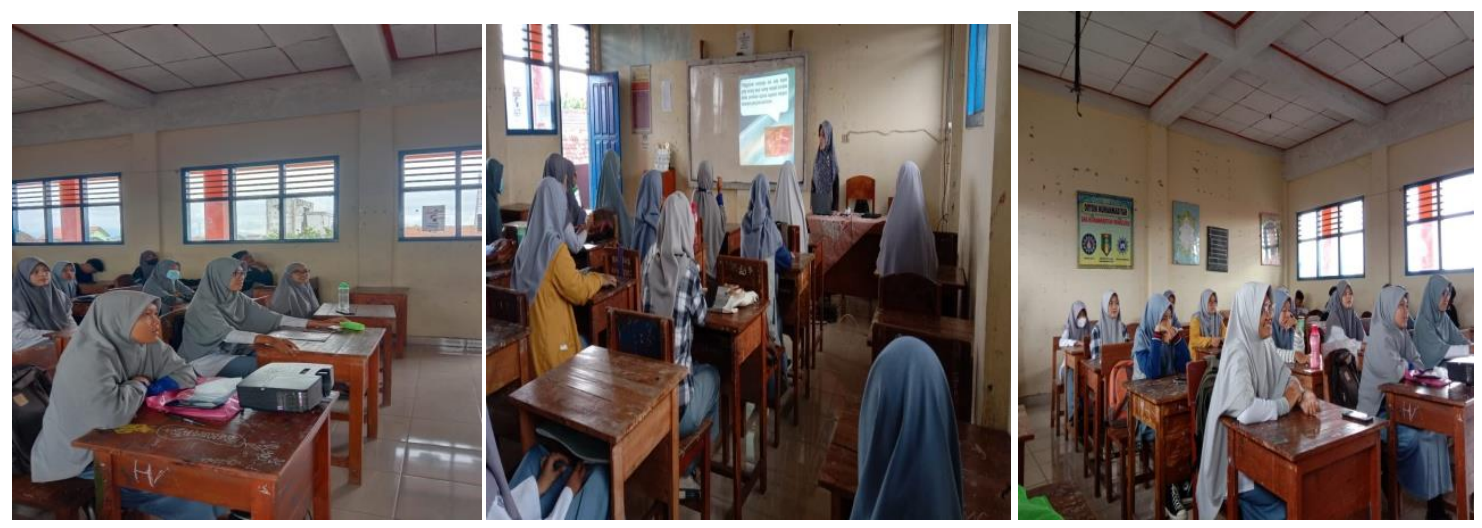

Gambar 1. Penyampaian materi dan sesi Tanya jawab 
Setelah kegiatan penyampaian materi dan sesi tanya jawab selesai, selanjutnya adalah kegiatan pelatihan kepada peserta didik kelas X SMA Muhammadiyah Pringsewu untuk praktik langsung membuat kalimat yang efektif sesuai dengan ketepatan konjungsi dan kata depan yang digunakan dalam tulisan. Peserta pelatihan dapat memilih konjungsi dan kata depan yang sesuai dengan kalimat yang akan dituliskan dalam laporan akhir. Akhirnya peserta pelatihan pengabdian masyarakat mampu memilih ketepatan konjungsi dan kata epan pada tulisan laporan akhir sekolah. Pemilhan konjungsi dan kata depan sangatlah penting dalam suatu tulisan baik itu karya ilmiah maupun laporan akhir sekolah yang akan dibuat dalam tugas akhir peserta didik ketika lulus.

Berdasarkan pelaksanaan kegiatan pelatihan pemakaian kata penghubung dan kata depan yang tidak tepat dalam bahasa Indonesia diperoleh hasil yaitu: (1) peserta pengabdian memiliki pengetahuan tentang pemilihan konjungsi dan kata depan yang tepat dalam bahasa Indonesia; (2) peserta pengabdian memiliki penguasaan wawasan kebahasaan dan keterampilan berbahasa dengan baik dan benar; (3) peserta pengabdian mampu membuat karya ilmiah maupun laporan akhir sekolah sesuai kaidah bahasa Indonesia.
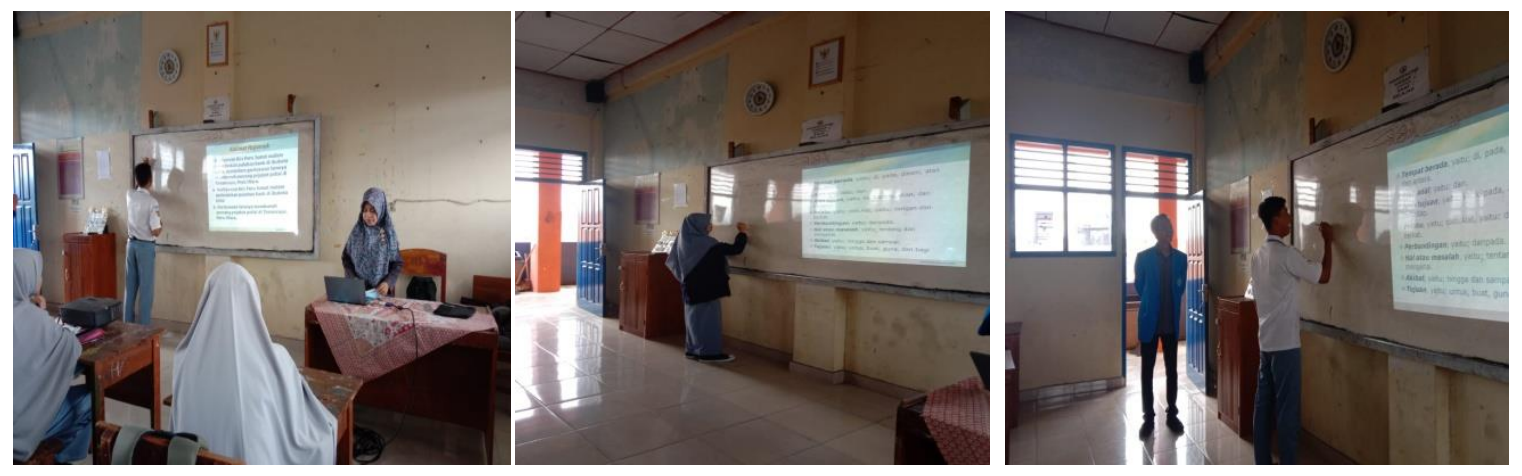

Gambar 2. Praktik saat membuat konjungsi yang tepat dalam kalimat

\section{SIMPULAN DAN SARAN}

Simpulan dari kegiatan pengabdian kepada masyarakat yang berbentuk pelatihan dengan judul pemakaian kata penghubung dan kata depan yang tidak tepat 
dalam bahasa Indonesia adalah memiliki pengetahuan tentang ketepatan pemakaian kata penghubung dan kata depan dalam penulisan karangan maupun karya tulis ilmiah dalam bahasa Idonesia, memiliki penguasaan kaidah atau ejaan bahasa Indonesia yang disempurnakan dalam tulisan yang baik, dan mampu menghasilkan tulisan yang produktif sesuai kaidah bahasa Indonesia. Saran yang dapat disampaikan dalam kegiatan pengabdian masyarakat ini yaitu (1) Peserta didik harus dapat membedakan antara konjungsi dan kata depan;, dan (2) Peserta didik hendaknya lebih teliti dalam pemakaian konjungsi maupun kata depan dalam tulisan karangan maupun laporan akhir .

\section{DAFTAR PUSTAKA}

Chaer, Abdul. (1990). Penggunaan Preposisi dan Konjungsi Bahasa Indonesia. Ende: Nusa Indah.

Kridalaksana, Harimurti. (1986). Fungsi Bahasa dan Sikap Bahasa. Ende: Nusa Indah.

Amalia, Febri, Bambang Hartono, dan Santi Pratiwi Tri Utami. (2018). Konjungsi Wacana Bahasa Indonesia pada Wacana Media Tulis (Online), Huku Teks (Pelajaran), dan Artikel Ilmiah. Jurnal Ssatra Indonesia 7 (1) 73-80.

Baiti, Nur. (2020). Analisis Penggunaan Konjungsi dalam Kumpulan Artikel pada Rubrik Politik Hukum Koran Kompas. Konfiks: Jurnal Bahasa, Sastra, dan Pengajaran 7 (1) 24-27.

Nugraha, Oktavian Aditya, Abdul Ngalim dan Yakub Nasucha. (2015). Penggunaan Konjunsi dalam Bahasa Tulis dan Lisan oleh Siswa Kelas Lima Sekolah Dasar Baki Pandeyan 01 Sukoharjo. Jurnal Penelitian Humaniora 16 (2) 4350.

Sari, Puspita Monika, Bambang Djunaidi dan Supadi. (2020). Konjungsi pada Harian Rakyat Bengkulu. Jurnal Ilmiah Korpus 4 (2) 205-214.

Kridalaksana, Harimurti. (2005). Kelas Kata dalam Bahasa Indonesia Edisi Kedua. Jakarta: Gramedia Pustaka Utama.

Ramlan, M., Wijana, I Dewa Putu., Mastoyo, Y.T., \& Sunarso. (1994). Bahasa Indonesia yang Salah dan yang Benar. Yogyakarta: Andi Offset.

Ramlan, M. (1980). Kata Depan atau preposisi dalam Bahasa Indonesia. Yogyakarta: Karyono. 